\section{A core-shell magnetic mesoporous silica sorbent for organic targets with high extraction performance and anti-interference ability $\dagger$}

\author{
Xiao-le Zhang, ${ }^{a b}$ Hong-yun Niu, ${ }^{a}$ Wen-hui Li, ${ }^{a}$ Ya-li Shi ${ }^{a}$ and Ya-qi Cai ${ }^{*}$ \\ Received 17th January 2011, Accepted 21st February 2011 \\ DOI: $10.1039 / \mathrm{clcc10300h}$
}

$\mathrm{C}_{18}$-functionalized mesoporous silica shell was successfully fabricated on the surface of an $\mathrm{Fe}_{3} \mathrm{O}_{4} / \mathrm{SiO}_{2}$ core to obtain an $\mathrm{Fe}_{3} \mathrm{O}_{4} / \mathrm{SiO}_{2} / \mathrm{SiO}_{2}-\mathrm{C}_{18}$ magnetic microsphere. The microsphere exhibited high extraction efficiency to organic targets and strong anti-interference ability to natural organic matter. It could be easily isolated from water solution after extraction.

Recently, magnetic nanoparticles (MNPs) have attracted much attention in preconcentration of target analytes from environmental water samples. ${ }^{1}$ These MNPs sorbents, with large surface area, can be quickly isolated from matrix solutions by using an external magnet after extraction. Therefore, high extraction performance is readily achieved and the solid-phase extraction (SPE) procedure is greatly simplified. However, MNPs with functional groups on the surface tend to aggregate in water solution, which decreases the adsorption ability of the sorbent. In addition, natural organic matter (NOM) in complex matrixes interferes with the extraction of targets by adhering to the surface of the sorbent and contaminating the sorbent. As a result, larger amounts of sorbent are necessary to extract trace targets from large volumes of water samples with complex matrixes. There is a requirement for more efficient magnetic sorbents with enhanced anti-interference ability. Mesoporous materials possess large surface area and uniform pore size distribution, and have been synthesized and applied in various scientific fields. ${ }^{2}$ We propose that high extraction efficiency and anti-interference ability can be achieved by using this kind of materials as SPE sorbent. Herein, we report a novel magnetic mesoporous silica (MMS) sorbent with $\mathrm{C}_{18}$-functionalized mesoporous silica shell and $\mathrm{Fe}_{3} \mathrm{O}_{4} / \mathrm{SiO}_{2}$ core and its application in extraction of trace organic targets from water solution.

Scheme 1 illustrates the synthesis of $\mathrm{Fe}_{3} \mathrm{O}_{4} / \mathrm{SiO}_{2} / \mathrm{SiO}_{2}-\mathrm{C}_{18}$ MMS sorbent. First, $\mathrm{Fe}_{3} \mathrm{O}_{4} \mathrm{MNPs}$ were synthesized by

${ }^{a}$ State Key Laboratory of Environmental Chemistry and Ecotoxicology, Research Center for Eco-Environmental Sciences, Chinese Academy of Sciences, P.O. Box 2871, Beijing 100085, China.E-mail: caiyaqi@rcees.ac.cn; Tel: +86-10-6284-9182

${ }^{b}$ College of Chemical Engineering and Biological Technology, Hebei United University, Tangshan, Hebei, 063000, China

$\dagger$ Electronic supplementary information (ESI) available: Synthesis and characterization of $\mathrm{Fe}_{3} \mathrm{O}_{4} / \mathrm{SiO}_{2} / \mathrm{SiO}_{2}-\mathrm{C}_{18}$ magnetic microsphere, magnetic solid-phase extraction procedure, HPLC-FLD analysis of PAHs, VSM magnetization curves and XRD patterns, effects of parameters on the extraction efficiency. See DOI: $10.1039 / \mathrm{clcc} 10300 \mathrm{~h}$ co-precipitation of a mixture of $\mathrm{FeCl}_{3} \cdot 6 \mathrm{H}_{2} \mathrm{O}$ and $\mathrm{FeCl}_{2}$. $4 \mathrm{H}_{2} \mathrm{O}$ with concentrated aqueous ammonia. ${ }^{3}$ After modification with trisodium citrate, the obtained MNPs were embedded in silica microsphere to get the monodisperse $\mathrm{Fe}_{3} \mathrm{O}_{4} / \mathrm{SiO}_{2}$ microsphere through a modified Stöber method. ${ }^{4}$ Then, a mesoporous silica shell was fabricated on the surface of the $\mathrm{Fe}_{3} \mathrm{O}_{4} / \mathrm{SiO}_{2}$ core to form a core-shell $\mathrm{Fe}_{3} \mathrm{O}_{4} / \mathrm{SiO}_{2} / \mathrm{SiO}_{2} \mathrm{MMS}$ microsphere by a soft template method. ${ }^{5}$ Finally, the inner and outer surfaces of the mesoporous silica shell were functionalized with $\mathrm{C}_{18}$ groups by silylation reaction ${ }^{6}$ after the soft template was removed by acidic ethanol solution. Detailed information about the synthesis and characterization of the MMS sorbent is provided in ESI. $\dagger$

Fig. 1 depicts the TEM images of $\mathrm{Fe}_{3} \mathrm{O}_{4} / \mathrm{SiO}_{2}, \mathrm{Fe}_{3} \mathrm{O}_{4} / \mathrm{SiO}_{2} /$ $\mathrm{SiO}_{2}$ and $\mathrm{Fe}_{3} \mathrm{O}_{4} / \mathrm{SiO}_{2} / \mathrm{SiO}_{2}-\mathrm{C}_{18}$ microspheres. The size of the $\mathrm{Fe}_{3} \mathrm{O}_{4} / \mathrm{SiO}_{2}$ microspheres (Fig. 1a) is 80-100 nm. Several $\mathrm{Fe}_{3} \mathrm{O}_{4}$ nanoparticles are embedded in each single silica microsphere. In Fig. $1 \mathrm{~b}$ and $\mathrm{c}$, the typical core-shell structure of the $\mathrm{Fe}_{3} \mathrm{O}_{4} / \mathrm{SiO}_{2} / \mathrm{SiO}_{2}$ microsphere can be discerned clearly. The $\mathrm{Fe}_{3} \mathrm{O}_{4} / \mathrm{SiO}_{2} / \mathrm{SiO}_{2}$ microsphere is about $200 \mathrm{~nm}$ in diameter and monodisperse in solution. The ordered mesoporous silica shell is $50 \mathrm{~nm}$ in thickness and possesses perpendicularly oriented channels of about $3 \mathrm{~nm}$ in diameter. After functionalization with $\mathrm{C}_{18}$ groups, the core-shell structure and monodisperse property of the obtained $\mathrm{Fe}_{3} \mathrm{O}_{4} / \mathrm{SiO}_{2} / \mathrm{SiO}_{2}-\mathrm{C}_{18}$ MMS microsphere are unchanged (Fig. 1d). But the diameter of the mesochannel decreases obviously, indicating that $\mathrm{C}_{18}$ groups are immobilized in the inner surface of the channel of the mesoporous silica shell.

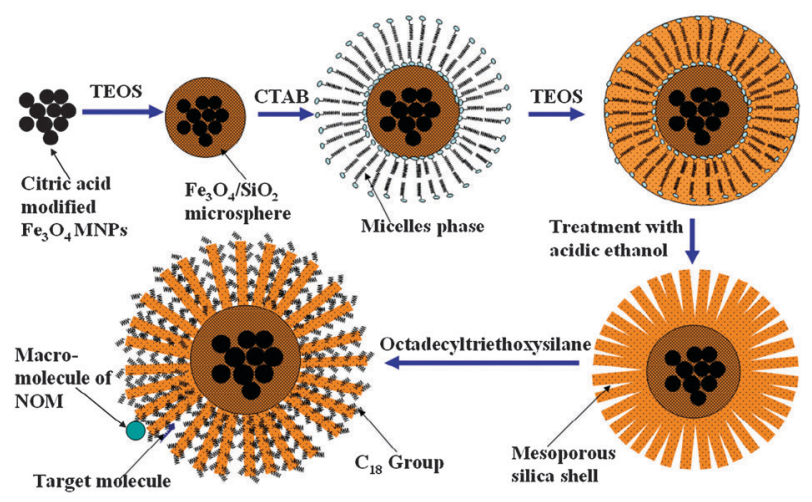

Scheme 1 Synthesis of $\mathrm{Fe}_{3} \mathrm{O}_{4} / \mathrm{SiO}_{2} / \mathrm{SiO}_{2}-\mathrm{C}_{18}$ microsphere. 


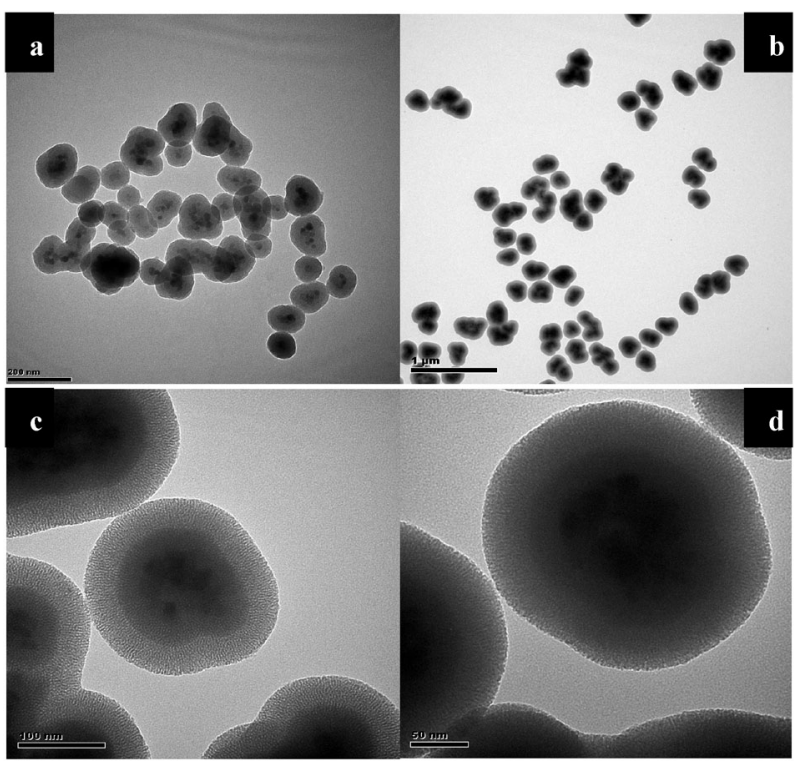

Fig. 1 TEM images of $\mathrm{Fe}_{3} \mathrm{O}_{4} / \mathrm{SiO}_{2}$ (a), $\mathrm{Fe}_{3} \mathrm{O}_{4} / \mathrm{SiO}_{2} / \mathrm{SiO}_{2}$ (b,c) and $\mathrm{Fe}_{3} \mathrm{O}_{4} / \mathrm{SiO}_{2} / \mathrm{SiO}_{2}-\mathrm{C}_{18}$ (d) microspheres.

The $\mathrm{N}_{2}$ sorption-desorption isotherms of $\mathrm{Fe}_{3} \mathrm{O}_{4} / \mathrm{SiO}_{2} / \mathrm{SiO}_{2}$ and $\mathrm{Fe}_{3} \mathrm{O}_{4} / \mathrm{SiO}_{2} / \mathrm{SiO}_{2}-\mathrm{C}_{18}$ microspheres (Fig. 2) both exhibit IV-type curves. ${ }^{5}$ A sharp peak of mesopore size distribution can be observed in both samples (Fig. 2, insets). The average mesopore size of $\mathrm{Fe}_{3} \mathrm{O}_{4} / \mathrm{SiO}_{2} / \mathrm{SiO}_{2}$ microsphere is $2.43 \mathrm{~nm}$, and its BET surface area and total pore volume are calculated to be $464 \mathrm{~m}^{2} \mathrm{~g}^{-1}$ and $0.396 \mathrm{~cm}^{3} \mathrm{~g}^{-1}$, respectively. After functionalization with $\mathrm{C}_{18}$ groups, the average mesopore size, surface area and total pore volume of $\mathrm{Fe}_{3} \mathrm{O}_{4} / \mathrm{SiO}_{2} / \mathrm{SiO}_{2}-\mathrm{C}_{18}$ decrease to $1.93 \mathrm{~nm}, 331 \mathrm{~m}^{2} \mathrm{~g}^{-1}$ and $0.275 \mathrm{~cm}^{3} \mathrm{~g}^{-1}$, respectively.

The peak at small angle in the low-angle XRD patterns of $\mathrm{Fe}_{3} \mathrm{O}_{4} / \mathrm{SiO}_{2} / \mathrm{SiO}_{2}$ and $\mathrm{Fe}_{3} \mathrm{O}_{4} / \mathrm{SiO}_{2} / \mathrm{SiO}_{2}-\mathrm{C}_{18}$ microspheres (Fig. S1a $\dagger$ ) reveals the short-range mesoscopic ordering characteristic of both samples. ${ }^{5}$ The pore size of $\mathrm{Fe}_{3} \mathrm{O}_{4} / \mathrm{SiO}_{2} /$ $\mathrm{SiO}_{2}$ microsphere is $3.9 \mathrm{~nm}$, calculated by the Scherrer equation. After being modified with $\mathrm{C}_{18}$ groups, the pore size decreases to $3.2 \mathrm{~nm}$. This is consistent with the results of TEM and BET measurement. The wide-angle XRD patterns of both the microspheres (Fig. $\mathrm{S} 1 \mathrm{~b} \dagger$ ) are similar to that of $\mathrm{Fe}_{3} \mathrm{O}_{4}$ MNPs. ${ }^{5}$ However, the characteristic diffraction peaks of $\mathrm{Fe}_{3} \mathrm{O}_{4} \mathrm{MNPs}$ are weakened because of the mesoporous silica shell, and the diffraction peak of amorphous silica appears.

In the IR spectra of $\mathrm{Fe}_{3} \mathrm{O}_{4}, \mathrm{Fe}_{3} \mathrm{O}_{4} / \mathrm{SiO}_{2}, \mathrm{Fe}_{3} \mathrm{O}_{4} / \mathrm{SiO}_{2} / \mathrm{SiO}_{2}$ and $\mathrm{Fe}_{3} \mathrm{O}_{4} / \mathrm{SiO}_{2} / \mathrm{SiO}_{2}-\mathrm{C}_{18}$ microspheres (Fig. 3), the peak around $3420 \mathrm{~cm}^{-1}$ was assigned to $-\mathrm{OH}$ group on the surface
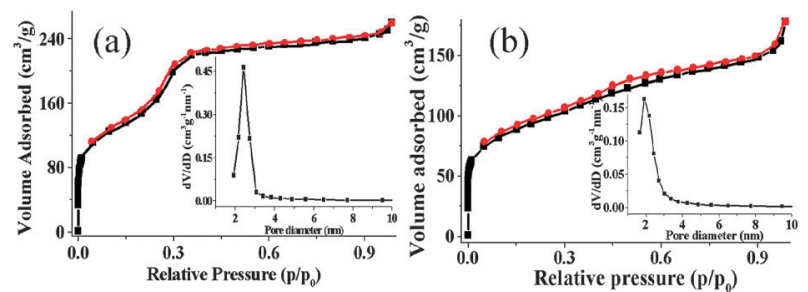

Fig. $2 \mathrm{~N}_{2}$ adsorption-desorption isotherms and mesopore size distribution (the insets) of $\mathrm{Fe}_{3} \mathrm{O}_{4} / \mathrm{SiO}_{2} / \mathrm{SiO}_{2}$ (a) and $\mathrm{Fe}_{3} \mathrm{O}_{4} / \mathrm{SiO}_{2}$ $\mathrm{SiO}_{2}-\mathrm{C}_{18}$ (b) microspheres. of the magnetic particles. The intensity of the peak at $560 \mathrm{~cm}^{-1}$, which is related to $\mathrm{Fe}-\mathrm{O}$ group, decreases with the thickening of the silica portion while a strong increase of the intensity of the $\mathrm{Si}-\mathrm{O}-\mathrm{Si}$ absorption at $1080 \mathrm{~cm}^{-1}$ is observed with the addition of the silica component. Characteristic bands of saturated $\mathrm{C}-\mathrm{H}$ stretching vibrations at 2851 and $2921 \mathrm{~cm}^{-1}$ demonstrate the successful modification of $\mathrm{C}_{18}$ group. ${ }^{6}$

All the vibrating sample magnetization (VSM) curves of $\mathrm{Fe}_{3} \mathrm{O}_{4} / \mathrm{SiO}_{2}, \quad \mathrm{Fe}_{3} \mathrm{O}_{4} / \mathrm{SiO}_{2} / \mathrm{SiO}_{2}$, and $\mathrm{Fe}_{3} \mathrm{O}_{4} / \mathrm{SiO}_{2} / \mathrm{SiO}_{2}-\mathrm{C}_{18}$ magnetic microspheres (Fig. S2a $\dagger$ ) have little hysteresis, remanence, and coercivity, which indicates the typical superparamagnetic characteristic of them. The saturation magnetizations decreased with the addition of nonmagnetic silica. The saturation magnetization of $\mathrm{Fe}_{3} \mathrm{O}_{4} / \mathrm{SiO}_{2} / \mathrm{SiO}_{2}-\mathrm{C}_{18}$ magnetic microsphere is $7.35 \mathrm{emu} \mathrm{g}^{-1}$ which is still sufficient for magnetic separation from water solution. (Fig. $\mathrm{S} 2 \mathrm{~b} \dagger$ )

The extraction performance of the $\mathrm{Fe}_{3} \mathrm{O}_{4} / \mathrm{SiO}_{2} / \mathrm{SiO}_{2}-\mathrm{C}_{18}$ sorbent to organic compounds was investigated with $500 \mathrm{~mL}$ of distilled water spiked with various targets $\left(20 \mathrm{ng} \mathrm{L}^{-1}\right)$. Polycyclic aromatic hydrocarbons (PAHs) were selected as targets for their carcinogenic or mutagenic property to human beings and toxicity to aquatic life. ${ }^{7}$ A HPLC-FLD system was employed in the determination of PAHs after enrichment with the MMS sorbent (detailed in ESI $\dagger$ ). The predominant factors affecting the extraction were investigated in terms of the recoveries of the targets. The interference of humic acid and protein in the extraction of PAHs was also studied.

The influence of solution $\mathrm{pH}$ in extraction of targets by the $\mathrm{Fe}_{3} \mathrm{O}_{4} / \mathrm{SiO}_{2} / \mathrm{SiO}_{2}-\mathrm{C}_{18}$ sorbent was investigated in the $\mathrm{pH}$ range of 3-11. The hydrophobic interaction between $\mathrm{C}_{18}$ group and nonpolar PAHs molecules is the principal contributor for the extraction and is hardly influenced by solution $\mathrm{pH}$. Therefore, the recoveries of PAHs almost remain constant in this $\mathrm{pH}$ range (Fig. S3 $\dagger$ ). The recoveries of most targets are up to $90 \%$ when $\mathrm{pH}$ is below 8.0. A slight decrease of recoveries at $\mathrm{pH}>8$ is observed and is perhaps caused by the instability of the bonding of $\mathrm{C}_{18}$ group on silica under this condition. To prove the contribution of $\mathrm{C}_{18}$ group to the extraction of PAHs, we performed the SPE of PAHs with $\mathrm{Fe}_{3} \mathrm{O}_{4} / \mathrm{SiO}_{2} / \mathrm{SiO}_{2}$ MMS microsphere without modification by $\mathrm{C}_{18}$ group. PAHs were hardly extracted by this material in the whole $\mathrm{pH}$ range. This result indicates that the $\mathrm{C}_{18}$ group is mainly responsible for the adsorption of PAHs on $\mathrm{Fe}_{3} \mathrm{O}_{4} / \mathrm{SiO}_{2} / \mathrm{SiO}_{2}-\mathrm{C}_{18}$ sorbent.

Ionic strength influences the adsorption of targets on sorbent by changing the charge density of the sorbent surface and the viscosity of solution. The inorganic ions in solution may enhance the hydrophobic interaction between $\mathrm{C}_{18}$ group and organic compounds, and thus promote the adsorption of targets on sorbent. (Fig. S4 $\dagger$ ) Therefore, $0.02 \mathrm{M} \mathrm{NaCl}$ was added to each sample before SPE to maintain the ionic strength of solution. High ionic strength has little influence on extraction efficiency of PAHs. Even when the concentration of $\mathrm{NaCl}$ is $0.1 \mathrm{M}$, the recoveries of most targets approach $90 \%$.

The obtained MMS microsphere has higher surface area to load more $\mathrm{C}_{18}$ groups than ordinary nanoparticles. Therefore, smaller amounts of the sorbent are expected to achieve satisfactory recoveries. Here, $30 \mathrm{mg}$ of $\mathrm{Fe}_{3} \mathrm{O}_{4} / \mathrm{SiO}_{2} / \mathrm{SiO}_{2}-\mathrm{C}_{18}$ sorbent is enough for quantitative extraction of trace targets from $500 \mathrm{~mL}$ of water solution in the optimal conditions and 


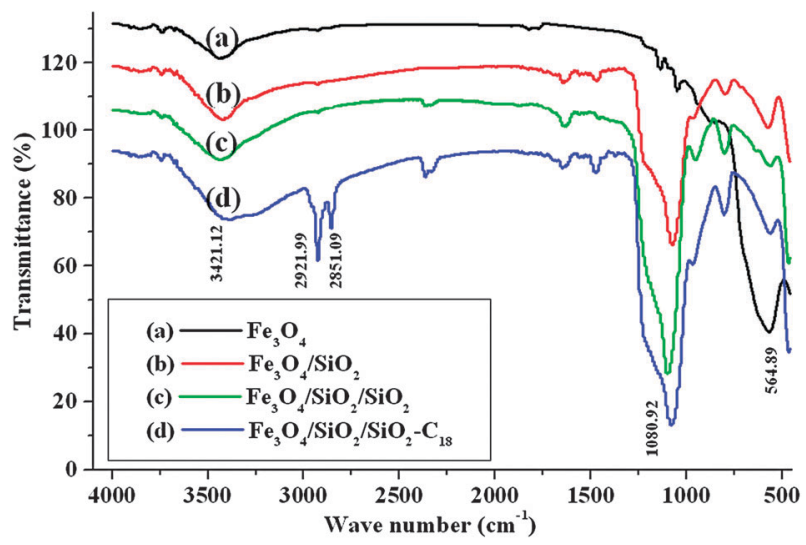

Fig. 3 IR spectra of $\mathrm{Fe}_{3} \mathrm{O}_{4}(\mathrm{a}), \mathrm{Fe}_{3} \mathrm{O}_{4} / \mathrm{SiO}_{2}$ (b), $\mathrm{Fe}_{3} \mathrm{O}_{4} / \mathrm{SiO}_{2} / \mathrm{SiO}_{2}$ (c) and $\mathrm{Fe}_{3} \mathrm{O}_{4} / \mathrm{SiO}_{2} / \mathrm{SiO}_{2}-\mathrm{C}_{18}$ (d) microspheres.

the recoveries of most targets are up to $90 \%$ (Fig.S5†). This reveals the high adsorption performance of the MMS sorbent.

The adsorption and desorption equilibrium may influence the recoveries of targets due to the special structure of the sorbent. In this study, ultrasonic treatment was performed both in the process of adsorption and desorption of PAHs. We find that the influence of equilibrium time is insignificant (Fig. S6†). This may be attributed to the fact that PAHs could be adsorbed onto the sorbent quickly and ultrasonic treatment also accelerated the extraction. In addition, $20 \mathrm{~min}$ was demanded for solid/liquid phase separation under magnetic field and the targets could also be adsorbed during the settlement of sorbent. Finally, 15 min was chosen as the stand time to get adsorption equilibrium. The influence of desorption conditions in the recoveries of targets was also investigated. Multiple elution and ultrasonic irradiation were found to facilitate the desorption of PAHs from the sorbent. Almost all targets were eluted from sorbent by using $12 \mathrm{~mL}$ of acetonitrile $(3 \mathrm{~mL}$ each time and washed four times, ultrasonic irradiation for $30 \mathrm{~s}$ during each elution), which was selected as the elution condition (Fig. S7†).

The anti-interference ability of the sorbent to NOM was tested by extracting trace targets in the presence of humic acid or protein. Humic acid and protein are very common in environmental water samples. Many organic compounds can be adsorbed on them due to their abundant functional groups. ${ }^{8}$ There is competitive adsorption toward targets between these NOMs and sorbent. Moreover, they also adhere to sorbent and occupy the adsorption sites, hence interfering with the extraction of targets. The recoveries of all targets decrease gradually with the increasing concentration of humic acid or bovine serum albumin (BSA), and the influence in more hydrophobic PAHs is relatively evident because of their higher affinity to these (Fig. S $8 \dagger$ and $\mathrm{S} 9 \dagger$ ). The influence of BSA in PAHs extraction is smaller than that of humic acid since the adsorption of PAHs on BSA is weaker than on humic acid. However the $\mathrm{Fe}_{3} \mathrm{O}_{4} / \mathrm{SiO}_{2} / \mathrm{SiO}_{2}-\mathrm{C}_{18}$ sorbent still possesses high anti-interference ability toward humic acid and protein because the unique perpendicular channels of the mesoporous silica shell could prevent the macromolecules from entering by size exclusion without influencing the extraction of target molecules. (See Scheme 1). In addition, the large surface area endows the sorbent with high adsorption ability. Even though the concentrations of humic acid and BSA reached $50 \mathrm{mg} \mathrm{L}^{-1}$ and $0.5 \mathrm{~g} \mathrm{~L}^{-1}$, respectively, the recoveries of most targets were higher than $60 \%$.

In summary, $\mathrm{Fe}_{3} \mathrm{O}_{4} / \mathrm{SiO}_{2}$ magnetic microsphere was coated with a $\mathrm{C}_{18}$-functionalized mesoporous silica shell to obtain a $\mathrm{Fe}_{3} \mathrm{O}_{4} / \mathrm{SiO}_{2} / \mathrm{SiO}_{2}-\mathrm{C}_{18}$ microsphere. The MMS sorbent exhibits ultrahigh extraction performance to hydrophobic compounds and can be easily isolated from water solution due to the superparamagnetic $\mathrm{Fe}_{3} \mathrm{O}_{4} / \mathrm{SiO}_{2}$ core. Solution $\mathrm{pH}$, high ionic strength and equilibrium time have little influence in the extraction. Furthermore, the sorbent could extract trace target analytes efficiently from water solutions with complex matrixes. To the best of our knowledge, this is the first report that $\mathrm{Fe}_{3} \mathrm{O}_{4} / \mathrm{SiO}_{2} / \mathrm{SiO}_{2}-\mathrm{C}_{18}$ magnetic mesoporous silica microspheres were synthesized and used for extraction of trace targets from large-volume water solutions.

We thank the National Natural Science Foundation (Grants 20877079, 20975110, and 20890111) and the National Basic Research Program of China (Grant 2010CB933500) for financial support.

\section{Notes and references}

1 (a) A. Ballesteros-Gómez and S. Rubio, Anal. Chem., 2009, 81, 9012; (b) Q. L. Zhang, F. Yang, F. Tang, K. Zeng, K. K. Wu, Q. Y. Cai and S. Z. Yao, Analyst, 2010, 135, 2426; (c) Y. Liu, H. F. Li and J. M. Lin, Talanta, 2009, 77, 1037; (d) X. L. Zhang, H. Y. Niu, Y. Y. Pan, Y. L. Shi and Y. Q. Cai, Anal. Chem., 2010, 82, 2363; (e) X. L. Zhao, Y. L. Shi, Y. Q. Cai and S. F. Mou, Environ. Sci. Technol., 2008, 42, 1201; (f) J. Ding, Q. Gao, D. Luo, Z. G. Shi and Y. Q. Feng, J. Chromatogr., A, 2010, 1217, 7351.

2 (a) M. Colilla, I. Izquierdo-Barba, S. Sánchez-Salcedo, J. L. G. Fierro, J. L. Hueso and M. Vallet-Regí, Chem. Mater., 2010, 22, 6459; (b) B. Muñoz, A. Rámila, J. Pérez-Pariente, I. Díaz and M. Vallet-Regí, Chem. Mater., 2003, 15, 500; (c) A. Sayari, S. Hamoudi and Y. Yang, Chem. Mater., 2005, 17, 212; (d) V. Polshettiwar, D. Cha, X. X. Zhang and J. M. Basset, Angew. Chem., Int. Ed., 2010, 49, 9652; (e) J. Kecht, A. Schlossbauer and T. Bein, Chem. Mater., 2008, 20, 7207; (f) T. Valdés-Solís, A. F. Rebolledo, M. Sevilla, P. Valle-Vigón, O. Bomatí-Miguel, A. B. Fuertes and P. Tartaj, Chem. Mater., 2009, 21, 1806.

3 H. Wei and E. K. Wang, Anal. Chem., 2008, 80, 2250.

4 Y. H. Deng, C. C. Wang, J. H. Hu, W. L. Yang and S. K. Fu, Colloids Surf., A, 2005, 262, 87.

5 Y. H. Deng, D. W. Qi, C. H. Deng, X. M. Zhang and D. Y. Zhao, J. Am. Chem. Soc., 2008, 130, 28.

6 Y. L. Liu and L. Jia, Microchem. J., 2008, 89, 72.

7 M. S. Garca-Falen, M. Prez-Lamela and J. Simal-Gndara, J. Agric. Food Chem., 2004, 52, 6897.

8 J. F. Liu, Z. S. Zhao and G. B. Jiang, Environ. Sci. Technol., 2008, 42, 6949. 